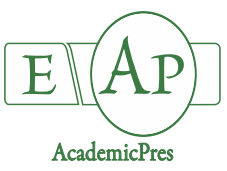

Możdżeń K et al. (2021)

Notulae Botanicae Horti Agrobotanici Cluj-Napoca

Volume 49, Issue 1, Article number 12195

DOI:10.15835/nbha49112195

Research Article

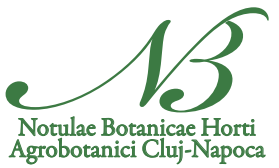

\title{
Germination and growth of radish under influence of nipplewort aqueous extracts
}

\author{
Katarzyna MOŻDŻEN' ${ }^{1 *}$, Beata BARABASZ-KRASNY ${ }^{1}$, \\ Alina STACHURSKA-SWAKON'², Ingrid TURISOVÁ ${ }^{3}$, \\ Peiman $\mathrm{ZANDI}^{4}$
}

\author{
${ }^{1}$ Pedagogical University of Krakow, Institute of Biology, Podchorązych 2 St., 30-084 Kraków, Poland; \\ katarzyna.mozdzen@up.krakow.pl (*correspondingauthor); beata.barabasz-krasny@up.krakow.pl \\ ${ }^{2} J a g i e l l o n i a n$ University, Institute of Botany, Gronostajowa 3 St., 30-387 Kraków, Poland; alina.stachurska-swakon@uj.edu.pl \\ ${ }^{3}$ Matej Bel University, Faculty of Natural Sciences, Department of Biology and Ecology, Tajovského 40 St., 97401 Banská Bystrica, \\ Slovakia; ingrid.turisova@umb.sk \\ ${ }^{4}$ Yibin University, International Faculty of Applied Technology, Yibin, Sichuan 644000 China; peiman.zandi@yibinu.edu.cn
}

\begin{abstract}
The conducted experiment was aimed at determining the effect of aqueous extracts from dry roots and shoots of common weed nipplewort (Lapsana communis L. subsp. communis) on seeds germination and early growth of radish (Raphanus sativus L. var. radicula Pers.), cultivars 'Rowa', 'Krakowianka', 'Półdługa'. The experiment was carried out in the form of Petri dishes tests with 3 different percentage concentrations of extracts $(1 \%, 3 \%$ and $5 \%$, respectively). The germination indexes used here revealed that the germination capacity of the radish seeds was significantly inhibited by extracts from the roots and shoots of $L$. communis subsp. communis. The elongation growth of radish roots and hypocotyls was stimulated to a higher percentage by extracts from nipplewort roots than by extracts from shoots. The fresh and dry mass of the radish seedlings depended on the type (roots/shoots) and concentration of the extract as well as the radish cultivar. The electrolyte leakage was the highest in seedlings watered with $5 \%$ extract of nipplewort shoots. The cultivar most sensitive to nipplewort extracts turned out to be 'Póldługa', and the least sensitive was 'Rowa'. The response of radish seeds to nipplewort extracts is probably due to the presence of allelochemical compounds and their synergistic interaction.
\end{abstract}

Keywords: allelopathy; germination; Lapsana communis subsp. communis; Raphanus sativus var. radicula; seeds; weeds

\section{Introduction}

Allelopathic compounds have been shown to play important roles in the determination of plant diversity, dominance, succession, climax of natural vegetation and in the plant productivity of agroecosystems (Chou, 1999; Duke et al., 2002). There are also some studies proved that allelopathic plant extracts performed better than synthetic herbicides to control weeds (Xuan et al., 2005; Jabran et al., 2010; Sołtys et al., 2013).

Received: 21 Dec 2020. Received in revised form: 18 Feb 2021. Accepted: 26 Feb 2021. Published online: 24 Mar 2021.

From Volume 49, Issue 1, 2021, Notulae Botanicae Horti Agrobotanici Cluj-Napoca journal will use article numbers in place of the traditional method of continuous pagination through the volume. The journal will continue to appear quarterly, as before, with four annual numbers. 
Thus, the plants are source of allelochemical compounds for sustainable agriculture (Kong, 2010; Rezendes et al., 2020). Some plants, that produce allelopathic compounds could be exploited in varied way in weed management, e.g. in cover crops (Urbano et al., 2006; Milchunas et al., 2011), rotation crops (Liebman and Staver, 2001). There are also ongoing studies on allelopathic influence of weed species as potential drivers for lowering crops (Jabran et al., 2010). In the last decade, there is a growing interest to estimate the allelopathic potential of different group of plants, e.g. medicine plants as they contain bioactive compounds (Fujii et al., 2003; Amini et al., 2014; Puła et al., 2020).

Lapsana communis L. (common nipplewort, Asteraceae Dum. family, Cichorioideae (Juss.) Chev. subfamily) is one of native weed species that commonly occurs in arable fields in Europe and western part of Asia. The species can be also found in hedges, roadsides, woods, wasteland, woodland margins and clear-felled areas in forests (Towpasz and Stachurska-Swakoń, 2008; Stachurska-Swakoń, 2009; Jarek and StachurskaSwakon, 2016). It was introduced to North America in the $19^{\text {th }}$ century, probably as the contamination of the garden material (Francis et al., 2011). It has been introduced also to South America (Argentina, Chile), Tasmania, New Zealand, Korea, Balearic Islands and others (Hulten and Fries, 1986; Francis et al., 2011). It is characteristic for Stellarietea mediae R.Tx., Lohm. et Prsg 1950 class, and Alliarion Oberd (1957) 1962 alliance from Artemisietea vulgaris Lohm., Prsg et R. Tx. in R.Tx. 1950 class (Matuszkiewicz, 2020). Recently, the species become more expansive spreading in a number of cropping system including cereals, fodder crops, vegetables, particularly in the eastern part of its range (Weber and Gut, 2005). In some European countries the species is listed as one of the most common weeds found in the wide spectrum of crops (after Francis et al., 2011).

L. communis is an annual (rarely perennial) herbaceous plant growing up to $1.2 \mathrm{~m}$ with an erect branching stem (Figure 1).

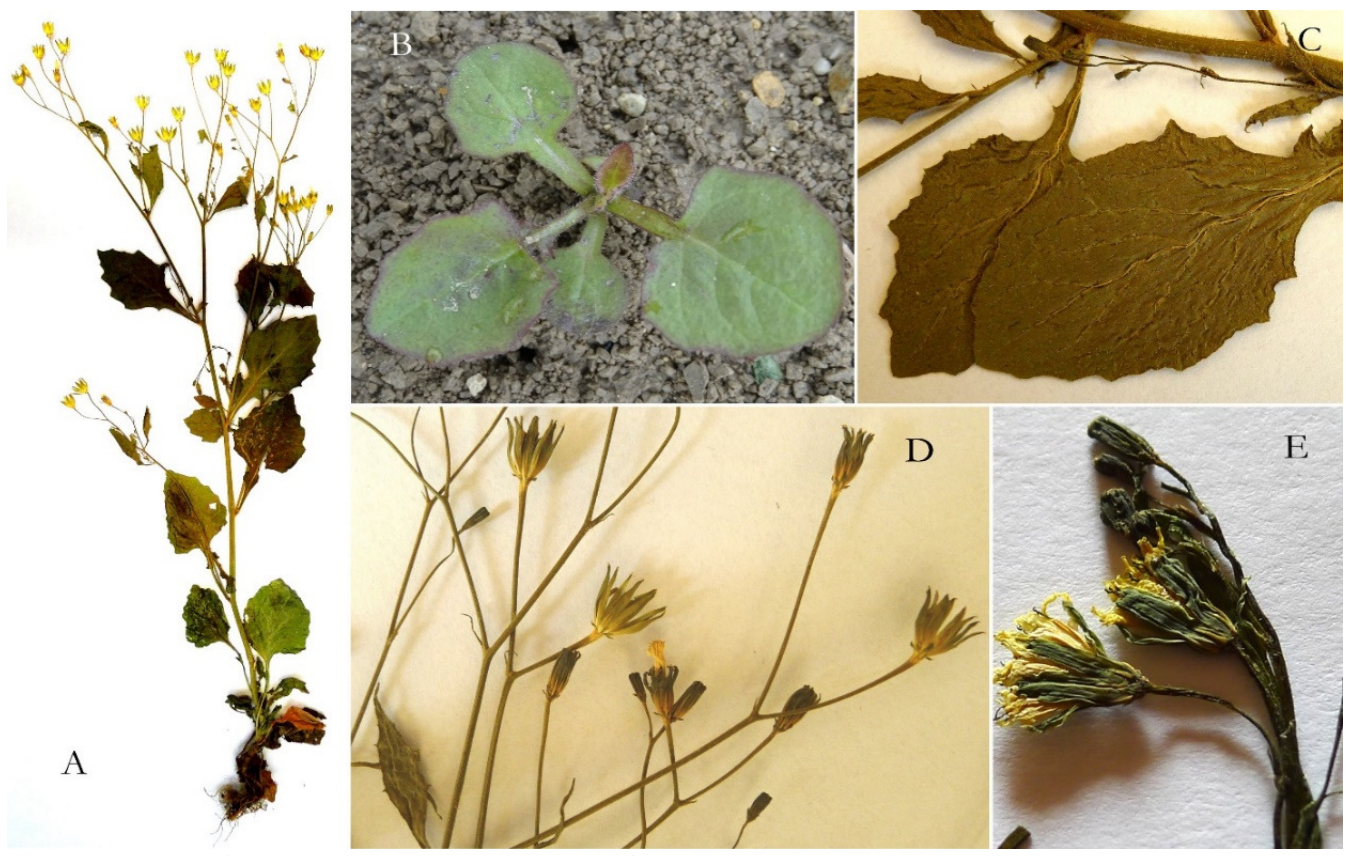

Figure. 1. Nipplewort Lapsana communnis L. subsp. communis

A - the whole plant, B - young aboveground leaves, C - part of a rough-hairy stem with leaves, D - complex umbellate inflorescences, E - inflorescence capitulas (photo B. Barabasz-Krasny and K. Możdżeń).

The plant produces numerous capitulas, $1-2 \mathrm{~cm}$ in diameters, in loose clusters at the top of the stems. The small yellow flowers bloom from May to September and they are pollinated by small insects. The species have also the ability to self-pollinate (Kashin et al., 2007). Its fruits are types achenes; they are dimorphic - outer 
are longer than inner: 3-4 mm long. The species reproduces only by seeds. One plant can produce about 1000 achenes, however in ruderal habitats the number of achenes could be higher (Bond et al., 2007 after Francis et al., 2011). The numerous small achenes are retained in the cypsela until the plant is shaken by the wind or a passing animal. After achenes dispersal, the lower leaves begin to rapidly senesce, however leaves and flower heads may remain on the stem into the fall (Francis et al., 2011). The seeds germinate mostly in next 2-3 years, and the very high rate of annual decline in the seed bank was observed (Roberts and Neilson, 1981; Barralis et al., 1988, the authors observation). Several subspecies of $L$. communis have been recognised (Sell, 1981), although subspecies communis is the most common across the most of Europe and in North America (Berkefeld, 1988). Other subspecies are e.g.: adenophora (Boiss.) Rech.f. - Southeast Europe, grandiflora (M. Bieb.) P.D. Sell. - Southwest Asia, intermedia (M. Bieb.) Hayek. (= L. intermedia M. Bieb.) - Southwest Asia and Southeast Europe. Most subspecies are distinguished from the typical by ligules more than twice as long as the involucre. Distinct ecotypes or races were also described in the main subspecies.

L. communis contains phenolic acids: caffeic, chlorogenic, caftaric and chicoric, flavonoids, isoquercitrin, luteolin and luteolin-7-O-b-glucuronide (Fontanel et al., 1998a). Its fatty acids consist of myristic, palmitic, 10,13- or 11, 14- octadecadienoic, a-linolenic, stearic and arachidic acids (Fontanel et al., 1998b). The triterpene alcohol with taraxerol, b-amyrin, germanicol, aamyrin, lupeol, cycloartenol and ctaraxasterol were also extracted from nipplewort (Fontanel et al., 1999). Its volatile oil at flowering stage consisted of limonene, acetophenone, nonanal, and others (Stanciu et al., 2007). The species was used in the folk medicine (for breast ulcers), and as edible in Turkey (Francis et al., 2011).

The aim of the study was to determine the influence of aqueous extracts from dry roots and shoots of nipplewort (Lapsana communis L. subsp. communis) - as common annual weed, on the germination and early growth of radish seeds (Raphanus sativus L. var. radicula Pers.) in cultivars 'Rowa', 'Krakowianka', 'Półdługa' with low environmental requirements and quick germination. In the study was measured: (1) seed germination indexes, (2) the elongation growth of seedlings, (3) fresh, dry masses and water content in seedlings, and (4) the electrolytes leakage from seedling cells.

\section{Materials and Methods}

\section{Plant material}

Lapsana communis L. subsp. communis roots and shoots were collected from orchards in Southern

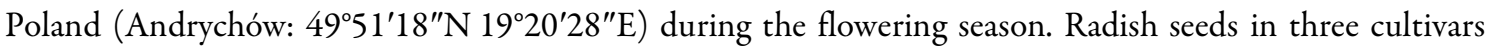
(Raphanus sativus L. var. radicula Pers. 'Rowa', 'Krakowianka' and 'Półdługa') from POLAN company were used in the experiment.

\section{Aqueous extracts preparation}

Fresh plant material was subjected to selection in order to eliminate defective individuals. Then, fully healthy roots and shoots of $L$. communis subsp. communis were dried in a laboratory drier (Wamed SUP-100, Warszawa, Poland) in the dark at $25^{\circ} \mathrm{C}$ for 5 days. After this period, the dry plant material was ground in a grinder (Braun, Poland) and stored in paper bags. Aqueous extracts of dry roots and shoots were prepared at 3 different percentage concentrations $(1 \%, 3 \%$ and $5 \%$, respectively). For this aim, the dry, fragmented plant organs were weighed in appropriate amounts and poured over with cold distilled water. Solutions from the roots and nipplewort shoots were prepared separately, according to the procedure: $1 \%$ - $1 \mathrm{~g}$ of plants material was poured with $99 \mathrm{ml}$ of distilled water, $3 \%$ - $3 \mathrm{~g}$ of plants material was poured with $97 \mathrm{ml}$ of distilled water and $5 \%-5 \mathrm{~g}$ of plants material, which was poured with $95 \mathrm{ml}$ of distilled water. The extracts were left for 24 hours in the dark in order to extract the chemicals they contained. One day later, the extracts were filtered through filter paper and stored in the dark at $6-8^{\circ} \mathrm{C}$ for the duration of the experiment. 


\section{Radish germination condition}

Radish seeds were sterilised in a $1 \%$ acetone solution for 5 minutes and washed 5 times with distilled water. Then seeds were placed in sterile petri dishes with 3 layers of filter paper which was moistened with $6 \mathrm{ml}$ of prepared aqueous extracts of nipplewort roots and shoots. 25 seeds were placed in each Petri dish. The Petri dishes with seeds were placed in a germinator in the dark, at $25^{\circ} \mathrm{C}$ temperature, $60-70 \%$ humidity. Every 24 hours, the number of germinated seeds was checked and the seeds were moistened with $2 \mathrm{ml}$ of extracts of the appropriate concentration. The control group was seeds watered with distilled water in the same volume as the experimental groups.

\section{Germination parameters}

Characterisation of the germination capacity of radish seeds, under the influence of aqueous $L$. communis subsp. communis extracts, were based on germination indexes. The percentage of germinated seeds (GP) (Khan et al., 2011), germination index (GI) (AOSA, 1983), speed of emergence (SE) (Islam et al., 2009), germination rate (GR) and germination seedling vigour index (SVI) (separately for roots, hypocotyls and whole seedlings) (Abdul-baki and Anderson, 1973) were measured.

$\mathrm{GP}=[$ germinated seed $/$ total seed $] \times 100 \quad(1)$

$\mathrm{GI}=[$ number of germinated seeds/days of first count $]+\ldots+[$ number of germinated seeds/days of last or final count]

$\mathrm{SE}=$ (number of germinated seeds at the starting day of germination/number of germinated seeds at the final days of measurement $) \times 100$

$$
\mathrm{GR}=[(\mathrm{n} 1+\mathrm{n} 2+\mathrm{nn}) /((\mathrm{n} 1 \times \mathrm{T} 1)+(\mathrm{n} 2 \times \mathrm{T} 2)+(\mathrm{n} 3 \times \mathrm{T} 3)+\ldots)] \times 100
$$

where: $\mathrm{n} 1=$ number of germinated seeds on time $\mathrm{T} 1 ; \mathrm{n} 2=$ number of germinated seeds on time T2; $\mathrm{n} 3$ $=$ number of germinated seeds on timeT3

$\mathrm{SVI}=($ organ seedling length $(\mathrm{cm}) \times$ percentage of germinated seeds $) / 100$

\section{Seedling growth}

The length of the seedlings was measured with a caliper (Topex 31C615, Poland) with an accuracy of 1 $\mathrm{mm}$. The seedling growth inhibition index was determined as $\%$ of control, according to the formula proposed by Islam et al. (2013). Negative values of the index indicate stimulation of growth, positive values of inhibition of elongation growth, expressed as a percentage of the control group.

$\mathrm{IP}=[1-(\mathrm{LE} / \mathrm{LC})] \times 100$

where: IP - growth inhibition index (\%), LE - seedling length $(\mathrm{cm})$ treated with aqueous extract, LC seedling length $(\mathrm{cm})$ from the control

\section{Fresh mass (FM), dry mass (DM), DM/FM, relative water content and total water content}

Fresh mass (FM) of 7-day-old radish seedlings was determined on the balance with an accuracy of 0.001 $\mathrm{g}$ (Ohaus Adventurer Pro, USA). Weighed seedlings were immersed for $24 \mathrm{~h}$ in petri dishes $(\varnothing 5 \mathrm{~cm})$ in $5 \mathrm{ml}$ of distilled water in order to determine the turgor index (TM). The seedlings were dried for $48 \mathrm{~h}$ at $105^{\circ} \mathrm{C}$ in a Wamed SUP-100 dryer (Poland) in order to determine the dry weight (DM). Based on the obtained mass results, the following were calculated: (7) - a relative water content (RWC), according to formula Mullan and Pietragalla (2012), and (8) - total water content (TWC), according to Lipniak and Kliszcz (2020).

$\mathrm{RWC}=[(\mathrm{FM}-\mathrm{DM}) /(\mathrm{TM}-\mathrm{DM})] \times 100$

where: RWC - relative water content, FM - fresh mass, DM - dry mass, TM - turgor mass (7)

$\mathrm{TWC}=100-[(\mathrm{DM} \times 100) / \mathrm{FM}]$

where: TWC - total water content, DM - dry mass, FM - fresh mass 


\section{Electrolyte leakage}

Permeability of cell membranes of radish seedlings by electrolyte leakage was measured according to the method used in paper Możdżeń et al. (2018). Individual seedling was placed in $15 \mathrm{ml}$ deionized water with a conductivity of $0.05 \mu \mathrm{S} / \mathrm{cm}$ in polypropylene violes, and shaken for $3 \mathrm{~h}$ on shaker model Rocker, Labnet (New Jersey, USA). The electrical conductivity of the diffusates (LZ) was measured using a conductivity meter CX701 type, Elmetron (Zabrze, Poland), with an electrode with a constant $\mathrm{K}=1.04$ (Elmetron, Zabrze, Poland). Then, samples were frozen at $-75^{\circ} \mathrm{C}$ for $24 \mathrm{~h}$ in order to macerate the tissues. After that time, the frozen plant material was subjected to the same shaking procedure as described above. Next, the total electrolyte leakage content from dead tissue (LM) were determined. The percentage electrolyte leakage (EL) from radish seedlings were made according to the formula:

$$
\mathrm{EL}=(\mathrm{LZ} / \mathrm{LM}) \times 100 \%
$$

\section{Statistical analysis}

The experiment was carried out in 3 replicates. The obtained results were summarised in Excel. The results between objects $(n=3, \pm S D)$ were analysed by the ANOVA parametric test using the post hoc Tukey test $\mathrm{p}<0.05$ in Statistica 13.0.

\section{Results}

\section{Germination parameters}

The Germination percentage (GP), for the 'Rowa' and 'Krakowianka' cultivars, was higher among seeds watered with $1 \%$ and $3 \%$ extracts from roots of Lapsana communis L. subsp. communis than the control values. For 'Półdługa' cultivar all extracts from nipplewort roots significantly decreased germination (Table 1).

Table 1. Germination indexes in radish seeds (Raphanus sativus L. var. radicula Pers. 'Rowa', 'Krakowianka', 'Półdługa') watered with aqueous extracts from roots and shoots Lapsana communis L. subsp. communis, with different percentages (1\%, 3\% and 5\%) and under control conditions

\begin{tabular}{|c|c|c|c|c|c|c|c|c|}
\hline \multirow{3}{*}{ Extract $(\%)$} & \multicolumn{2}{|c|}{ GP } & \multicolumn{2}{|c|}{ GI } & \multicolumn{2}{|c|}{ SE } & \multicolumn{2}{|c|}{ GR } \\
\hline & \multicolumn{8}{|c|}{ 'Rowa' } \\
\hline & root & shoot & root & shoot & root & shoot & root & shoot \\
\hline Control & \multicolumn{2}{|c|}{$60.00 \mathrm{~b}$} & \multicolumn{2}{|c|}{$49.36 \mathrm{~b}$} & \multicolumn{2}{|c|}{$60.80 \mathrm{c}$} & \multicolumn{2}{|c|}{$23.36 \mathrm{a}$} \\
\hline 1 & $86.68 \mathrm{a}$ & $90.68 \mathrm{a}$ & $60.27 \mathrm{a}$ & $61.66 \mathrm{a}$ & $86.68 \mathrm{a}$ & $90.68 \mathrm{a}$ & $24.47 \mathrm{a}$ & $24.64 \mathrm{a}$ \\
\hline 3 & $80.00 \mathrm{a}$ & $9.32 \mathrm{~d}$ & $56.88 \mathrm{ab}$ & $17.31 \mathrm{~d}$ & $80.00 \mathrm{ab}$ & $14.87 \mathrm{e}$ & $24.11 \mathrm{a}$ & $20.17 \mathrm{~b}$ \\
\hline 5 & $32.00 \mathrm{c}$ & $5.32 \mathrm{e}$ & $40.81 \mathrm{bc}$ & $8.48 \mathrm{e}$ & $37.51 \mathrm{~d}$ & $14.26 \mathrm{e}$ & $23.08 \mathrm{a}$ & $19.44 \mathrm{c}$ \\
\hline & \multicolumn{8}{|c|}{ 'Krakowianka' } \\
\hline Control & \multicolumn{2}{|c|}{$60.00 \mathrm{c}$} & \multicolumn{2}{|c|}{$43.62 \mathrm{~b}$} & \multicolumn{2}{|c|}{$60.80 c$} & \multicolumn{2}{|c|}{$23.36 \mathrm{a}$} \\
\hline 1 & $92.00 \mathrm{a}$ & $76.00 \mathrm{~b}$ & $61.23 \mathrm{a}$ & $55.79 \mathrm{ab}$ & $95.83 \mathrm{a}$ & $78.09 \mathrm{~b}$ & $24.89 \mathrm{a}$ & $24.14 \mathrm{a}$ \\
\hline 3 & $92.00 \mathrm{a}$ & $14.68 \mathrm{~d}$ & $61.23 \mathrm{a}$ & $17.08 \mathrm{c}$ & $95.83 \mathrm{a}$ & $31.45 \mathrm{~d}$ & $24.89 \mathrm{a}$ & $21.50 \mathrm{ab}$ \\
\hline 5 & $80.00 \mathrm{~b}$ & $5.32 \mathrm{e}$ & $56.47 \mathrm{ab}$ & $6.44 \mathrm{~d}$ & $86.96 \mathrm{ab}$ & $30.72 \mathrm{~d}$ & $24.62 \mathrm{a}$ & $21.82 \mathrm{ab}$ \\
\hline & \multicolumn{8}{|c|}{ 'Półdługa' } \\
\hline Control & \multicolumn{2}{|c|}{$60.00 \mathrm{a}$} & \multicolumn{2}{|c|}{$49.36 \mathrm{a}$} & \multicolumn{2}{|c|}{$60.80 \mathrm{a}$} & \multicolumn{2}{|c|}{$23.36 \mathrm{a}$} \\
\hline 1 & $16.00 \mathrm{c}$ & $32.00 \mathrm{~b}$ & $39.90 \mathrm{~b}$ & $19.02 \mathrm{c}$ & $16.00 \mathrm{c}$ & $32.43 \mathrm{~b}$ & $22.13 \mathrm{a}$ & $22.89 \mathrm{a}$ \\
\hline 3 & $4.00 \mathrm{~d}$ & $2.68 \mathrm{de}$ & $32.72 \mathrm{~b}$ & $6.97 \mathrm{e}$ & $4.92 \mathrm{~d}$ & $2.75 \mathrm{e}$ & $22.23 \mathrm{a}$ & $18.87 \mathrm{~b}$ \\
\hline 5 & $2.00 \mathrm{e}$ & $0.00 \mathrm{f}$ & $10.93 \mathrm{~d}$ & $1.21 \mathrm{f}$ & $0.00 \mathrm{f}$ & $0.00 \mathrm{f}$ & $19.87 \mathrm{~b}$ & $17.38 \mathrm{~b}$ \\
\hline
\end{tabular}

Mean values $(\mathrm{n}=3$ ) marked different letter differ statistically (in column - for each cultivar separately) according to Tukey test at $\mathrm{p}<0.05$ 
Statistically, the lowest number of germinated seeds was found for all radish cultivars on Petri dishes with 5\% nipplewort root extracts. In the case of extracts from nipplewort shoots, an increase in GP value was observed for seeds of the 'Rowa' and 'Krakowianka' cultivars, watered with $1 \%$ extracts, and a marked decrease in the value of this index for 'Półdługa' seeds. Shoot extracts at the concentration of 3\% and 5\% inhibited the germination of seeds of all three radish cultivars, compared to the control.

For 'Rowa' cultivar, $1 \%$ extract from roots of $L$. communis subsp. communis significantly increased the germination index (GI) values (Table 1). The other two concentrations of extracts (3\% and 5\%) did not significantly affect on the GI. In comparison to the control, the aqueous extracts from nipplewort roots, regardless of concentration, stimulated the GI values of the 'Krakowianka' cultivar, and inhibited the GI of the 'Półdługa'. In the case of $1 \%$ extracts from nipplewort shoots, an increase in the GI value was observed for 'Rowa' and 'Krakowianka' seedlings. The extracts of 3\% and 5\% concentrations significantly decreased the values of this index. For 'Półdługa' cultivar, all shoot extracts, regardless of concentration, had a negative effect on the GI values.

The seed emergence expressed as SE index values, for 'Rowa' cultivar, was stimulated by $1 \%$ and $3 \%$ of extracts from the roots of $L$. communis subsp. communis, compared to the control (Table 1 ). Contrary to the $5 \%$ extracts which clearly inhibited the SE. For the 'Krakowianka' cultivar a positive effect of all nipplewort root extracts on the SE parameter was revealed. Only for 'Półdługa' cultivar, each of the root extracts had a significant and negative effect on the SE values. In the case of shoot extracts, for the 'Rowa' and 'Krakowianka' cultivars, a positive effect of $1 \%$ concentrations on the SE parameter was observed. Compared to the control, only the 3\% and 5\% extracts reduced the seed emergence of these cultivars. On the other hand, for the 'Półdługa' cultivar, all extracts from shoots of $L$. communis subsp. communis had a negative effect on the SE values.

The germination rate (GR) values for all investigated radish cultivars was similar between the root extracts and the control (Table 1). The exception was the 5\% extract, which for the 'Póldluga' cultivar significantly decreased the GR values. For the 'Rowa' and 'Półdluga' cultivars, the $3 \%$ and $5 \%$ extracts from nipplewort shoots caused a significant reduction in the GR value, compared to the $1 \%$ extract and control group. For the 'Krakowianka' cultivar, the values of this parameter did not change significantly.

The seed vigour (presented as SVI index values) for the underground part of the 'Rowa' cultivar did not change in the presence of all the applied aqueous concentrations of nipplewort root extracts, compared to the control (Figure 2). In the case of the 'Krakowianka' and 'Półdluga' cultivars, each of the extracts accelerated the growth of seedlings. SVI of hypocotyl values increased significantly only for the 'Rowa' cultivar. For 'Krakowianka' and 'Półdługa' no effect of root extracts on the values of SVI hypocotyl index was observed. The SVI whole seedling values analysis for the 'Rowa' cultivar showed significant reduction of the SVI parameter on the 3\% nipplewort root extracts. With the other two extracts SVI index stimulation was observed, but it was not statistically significant. For the 'Krakowianka' and 'Półdługa' cultivars, extracts from the roots of $L$. communissubsp. communis positively influenced on the SVI whole seedling values, as compared to the control.

For the 'Rowa' cultivar, 1\% aqueous extracts from nipplewort shoots stimulated the SVI root index, compared to other concentrations and radish cultivars (Figure 2). A significant reduction in the SVI root values, for all three radish cultivars, was observed for 3\% and 5\% of L. communis subsp. communis extracts, compared to the control values. SVI hypocotyl values were significantly the highest for seedlings, all three cultivars, watered with $1 \%$ shoot extracts. The SVI whole seedling index showed a significant increase in the organs of radish seedlings watered with $1 \%$ nipplewort shoot extracts, compared to the control and the other two extracts. Extracts with a concentration of 3\% did not statistically significantly affect of the value of this parameter, although its reduction was observed compared to the control. For all three radish cultivars watered with $5 \%$ nipplewort shoot extracts a significant reduction of SVI whole seedling was found. 

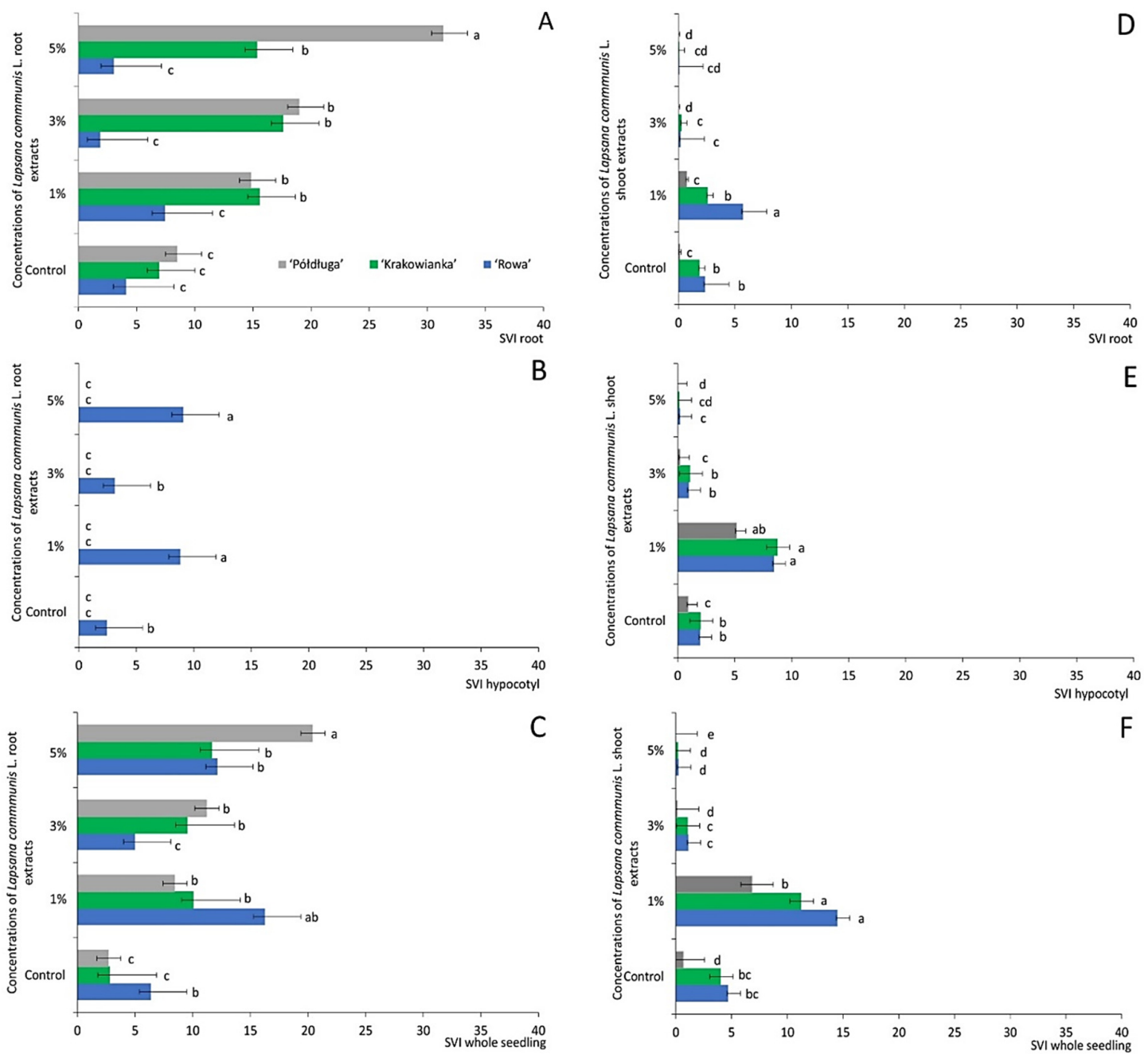

Figure 2. Comparison of seed vigour index (SVI) of seedlings organs

(root - A, D, hypocotyl - B, E and whole seedling - C, F) of Raphanus sativus L. var. radicula Pers. 'Rowa', 'Krakowianka' and 'Półdługa', after 7 days of watered with aqueous extracts from roots (A-C) and shoots (D-F) of Lapsana communis L. subsp. communis, with different concentration $(1 \% ; 3 \%$ and $5 \%)$ and control conditions; mean values $(\mathrm{n}=3, \pm \mathrm{SD})$ marked different letter differ statistically according to Tukey test at $\mathrm{p}<0.05$

\section{Seedlings growth}

The elongation length of radish seedling roots, presented as the Inhibition percentage index (IP), was stimulated, regardless of radish cultivar and nipplewort root extract concentrations (Figure 3, Table 2). The 'Rowa' cultivar, in which the elongation of seedling roots was significantly inhibited by extracts of $3 \%$ and $5 \%$, turned out to be an exception. IP of hypocotyl was similar and clearly stimulated by nipplewort root extracts. Biometric analysis of seedlings showed that the whole seedlings were stimulated by all extracts from $L$. communis subsp. communis. Positive values of elongation index were obtained only for the 'Rowa' cultivar, watered with 3\% extract. The length of root (expressed as IP of root values), of radish seedlings germinated on the shoot extracts, was inhibited by $3 \%$ and $5 \%$ extract concentrations. 

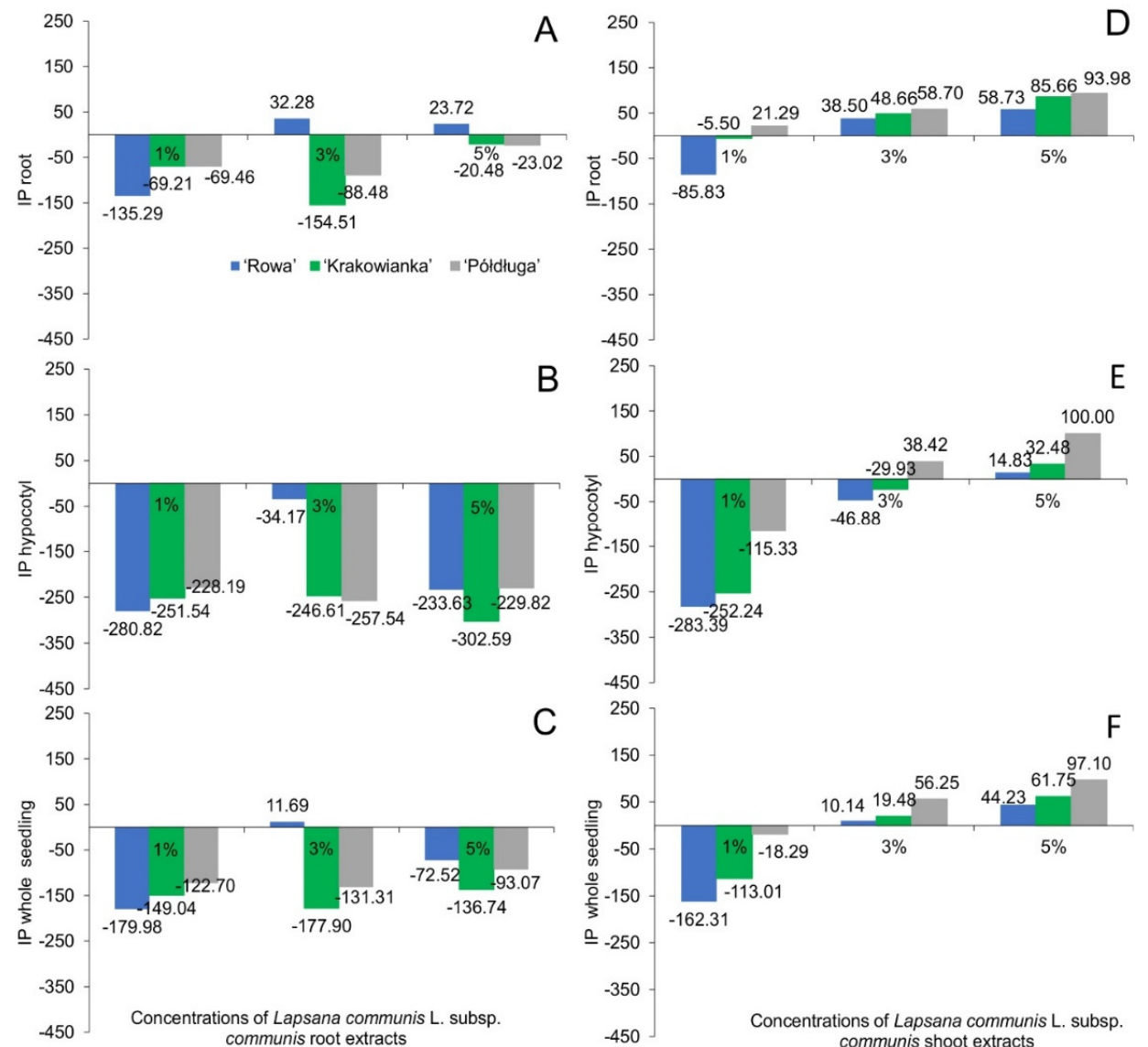

Figure 3. Comparison of IP - inhibition percentage values (expressed as a control) of seedlings organs (root - A, D, hypocotyl - B, E and whole seedling - C, F) of Raphanus sativus L. var. radicula Pers. 'Rowa', 'Krakowianka' and 'Półdługa', after 7 days of watered with aqueous extracts from roots (A-C) and shoots (D-F) of Lapsana communis L. subsp. communis, with different concentration (1\%; $3 \%$ and $5 \%)$

Table 2. Length of Raphanus sativus L. var. radicula Pers. 'Rowa', 'Krakowianka' and 'Półdługa' seedlings organs after 7 days of watered with aqueous extracts from roots and shoots Lapsana communis L. subsp. communis with different percentages $(1 \% ; 3 \%$ and $5 \%)$ and under control conditions

\begin{tabular}{|c|c|c|c|c|c|c|c|}
\hline \multirow{3}{*}{ Radish cultivars } & \multicolumn{7}{|c|}{ Concentrations of extracts (\%) } \\
\hline & \multirow{2}{*}{ Control } & \multicolumn{2}{|c|}{1} & \multicolumn{2}{|c|}{3} & \multicolumn{2}{|c|}{5} \\
\hline & & root & shoot & root & shoot & root & shoot \\
\hline \multicolumn{8}{|c|}{$\operatorname{Root}(\mathrm{cm})$} \\
\hline 'Rowa' & $3.94 \mathrm{c}$ & $7.44 \mathrm{a}$ & $6.30 \mathrm{~b}$ & $1.86 \mathrm{e}$ & $1.98 \mathrm{e}$ & $2.60 \mathrm{~d}$ & $1.30 \mathrm{e}$ \\
\hline 'Krakowianka' & $3.44 \mathrm{c}$ & $5.30 \mathrm{~b}$ & $3.36 \mathrm{c}$ & $7.74 \mathrm{a}$ & $1.54 \mathrm{~d}$ & $3.38 \mathrm{c}$ & $0.42 \mathrm{e}$ \\
\hline 'Półdługa' & $4.54 \mathrm{~b}$ & $6.44 \mathrm{a}$ & $2.32 \mathrm{c}$ & $6.34 \mathrm{a}$ & $1.10 \mathrm{~d}$ & $4.64 \mathrm{~b}$ & $0.18 \mathrm{e}$ \\
\hline \multicolumn{8}{|c|}{ Hypocotyl $(\mathrm{cm})$} \\
\hline 'Rowa' & $2.36 \mathrm{~d}$ & $8.84 \mathrm{a}$ & $8.80 \mathrm{a}$ & $3.14 \mathrm{c}$ & $3.30 \mathrm{c}$ & $7.76 \mathrm{~b}$ & $1.86 \mathrm{e}$ \\
\hline 'Krakowianka' & $2.74 \mathrm{~d}$ & $9.64 \mathrm{~b}$ & $9.62 \mathrm{~b}$ & $9.14 \mathrm{~b}$ & $3.30 \mathrm{c}$ & $10.72 \mathrm{a}$ & $1.86 \mathrm{e}$ \\
\hline 'Półdługa' & $2.60 \mathrm{~d}$ & $8.42 \mathrm{~b}$ & $5.44 \mathrm{c}$ & $9.10 \mathrm{a}$ & $1.58 \mathrm{e}$ & $8.42 \mathrm{~b}$ & $0.00 \mathrm{f}$ \\
\hline \multicolumn{8}{|c|}{ Whole seedling $(\mathrm{cm})$} \\
\hline 'Rowa' & $6.30 \mathrm{~d}$ & $16.28 \mathrm{a}$ & $15.10 \mathrm{~b}$ & $5.00 \mathrm{e}$ & $5.28 \mathrm{e}$ & $10.36 \mathrm{c}$ & $3.16 \mathrm{f}$ \\
\hline 'Krakowianka' & $6.18 \mathrm{~d}$ & $14.94 \mathrm{~b}$ & $12.98 \mathrm{c}$ & $16.88 \mathrm{a}$ & $4.84 \mathrm{e}$ & $14.10 \mathrm{~b}$ & $2.28 \mathrm{f}$ \\
\hline 'Półdługa' & $7.24 \mathrm{c}$ & $14.86 \mathrm{a}$ & $7.76 \mathrm{c}$ & $15.44 \mathrm{a}$ & $2.68 \mathrm{~d}$ & $12.96 \mathrm{~b}$ & $0.18 \mathrm{e}$ \\
\hline
\end{tabular}

mean values $(\mathrm{n}=3)$ marked different letter (in row - for each cultivar separately) differ statistically according to Tukey test at $\mathrm{p}<0.05$ 
With increasing of the allelochemical substances concentrations, a decrease in the ability of root development was observed, in all the tested radish cultivars. Except for two cultivars - 'Rowa' and 'Krakowianka' germinated on $1 \%$ of the extracts. The length of hypocotyl was stimulated with $1 \%$ shoots extracts. The other two extracts (3\% and 5\%) negatively influenced on the elongation of hypocotyls. The exception was the 'Rowa' and 'Krakowianka', in which the $3 \%$ extract stimulated the hypocotyls elongation.

The length of whole seedlings reached negative values only in seedlings watered with $1 \%$ of nipplewort shoot extracts. The seedlings germinated on the $3 \%$ and $5 \%$ extracts achieved positive values of the IP index, which indicated a negative effect of the extracts. With increasing of shoot extracts concentrations, the IP values increased (values closer to zero). It was a signal of the negative influence of the extracts on the elongation growth of radish seedlings (Figure 3, Table 2).

\section{Fresh mass (FM), dry mass (DM), DM/FM, relative water content and total water content}

Fresh mass (FM) of 'Rowa' seedlings was the highest in those watered with $1 \%$ extracts from shoot of Lapsana communis L. subsp. communis, compared to the control and other extracts. The FM of 'Rowa' seedlings was significantly inhibited by $5 \%$ extracts from roots and shoots (Table 3 ).

Table 3. Fresh and dry mass, relative water content and total water content in radish seedlings (Raphanus sativus L. var. radicula Pers. 'Rowa', 'Krakowianka', 'Półdługa') watered with aqueous extracts from roots and shoots Lapsana communis L. subsp. communis with different percentages (1\%;3\% and 5\%) and under control conditions

\begin{tabular}{|c|c|c|c|c|c|c|c|}
\hline \multirow{3}{*}{ Radish cultivars } & \multicolumn{7}{|c|}{ Concentrations of extracts (\%) } \\
\hline & \multirow{2}{*}{ Control } & \multicolumn{2}{|c|}{1} & \multicolumn{2}{|c|}{3} & \multicolumn{2}{|c|}{5} \\
\hline & & root & shoot & root & shoot & root & shoot \\
\hline \multicolumn{8}{|c|}{ Fresh mass FM (g) } \\
\hline 'Rowa' & $0.2101 \mathrm{~b}$ & $0.1798 \mathrm{bc}$ & $0.3262 \mathrm{a}$ & $0.0842 \mathrm{~d}$ & $0.1651 \mathrm{bc}$ & $0.1329 \mathrm{c}$ & $0.1283 \mathrm{c}$ \\
\hline 'Krakowianka' & $0.2150 \mathrm{a}$ & $0.2055 \mathrm{a}$ & $0.1944 \mathrm{ab}$ & $0.2076 \mathrm{a}$ & $0.2624 \mathrm{a}$ & $0.2504 \mathrm{a}$ & $0.1421 \mathrm{~b}$ \\
\hline 'Półdługa' & $0.1507 \mathrm{a}$ & $0.1594 \mathrm{a}$ & $0.1169 \mathrm{ab}$ & $0.1653 \mathrm{a}$ & $0.1813 \mathrm{a}$ & $0.1349 \mathrm{ab}$ & $0.0428 \mathrm{c}$ \\
\hline \multicolumn{8}{|c|}{ Relative water content RWC (\%) } \\
\hline 'Rowa' & $77.56 \mathrm{~b}$ & $87.40 \mathrm{~b}$ & $156.13 \mathrm{a}$ & $65.33 \mathrm{~b}$ & $74.56 \mathrm{~b}$ & $70.88 \mathrm{~b}$ & $72.49 \mathrm{~b}$ \\
\hline 'Krakowianka' & $81.52 \mathrm{a}$ & $83.26 \mathrm{a}$ & $78.08 \mathrm{a}$ & $88.70 \mathrm{a}$ & $81.90 \mathrm{a}$ & $83.14 \mathrm{a}$ & $82.49 \mathrm{a}$ \\
\hline 'Półdługa' & $89.34 \mathrm{a}$ & $91.34 \mathrm{a}$ & $100.81 \mathrm{a}$ & $82.80 \mathrm{ab}$ & $81.50 \mathrm{ab}$ & $64.46 \mathrm{~b}$ & $55.58 \mathrm{~b}$ \\
\hline \multicolumn{8}{|c|}{ Dry mass DM (g) } \\
\hline 'Rowa' & $0.0065 \mathrm{a}$ & $0.0053 \mathrm{~b}$ & $0.0056 \mathrm{~b}$ & $0.0054 \mathrm{~b}$ & $0.0065 \mathrm{a}$ & $0.0063 \mathrm{a}$ & $0.0067 \mathrm{a}$ \\
\hline 'Krakowianka' & $0.0080 \mathrm{a}$ & $0.0075 \mathrm{ab}$ & $0.0073 \mathrm{ab}$ & $0.0059 \mathrm{~b}$ & $0.0093 \mathrm{a}$ & $0.0104 \mathrm{a}$ & $0.0073 \mathrm{ab}$ \\
\hline 'Półdługa' & $0.0074 \mathrm{a}$ & $0.0056 \mathrm{~b}$ & $0.0056 \mathrm{~b}$ & $0.0058 \mathrm{~b}$ & $0.0066 \mathrm{a}$ & $0.0070 \mathrm{a}$ & $0.0060 \mathrm{a}$ \\
\hline \multicolumn{8}{|c|}{ Total water content TWC (\%) } \\
\hline 'Rowa' & $96.82 \mathrm{a}$ & $96.97 \mathrm{a}$ & $97.16 \mathrm{a}$ & $94.51 \mathrm{a}$ & $96.10 \mathrm{a}$ & $95.13 \mathrm{a}$ & $94.90 \mathrm{a}$ \\
\hline 'Krakowianka' & $96.32 \mathrm{a}$ & $96.36 \mathrm{a}$ & $96.33 \mathrm{a}$ & $97.04 \mathrm{a}$ & $96.39 \mathrm{a}$ & $95.79 \mathrm{a}$ & $94.91 \mathrm{a}$ \\
\hline 'Półdługa' & $95.10 \mathrm{a}$ & $96.51 \mathrm{a}$ & $95.07 \mathrm{a}$ & $96.48 \mathrm{a}$ & $96.46 \mathrm{a}$ & $94.68 \mathrm{a}$ & $83.98 \mathrm{~b}$ \\
\hline \multicolumn{8}{|c|}{ Dry mass / Fresh mass ratio DM/FM } \\
\hline 'Rowa' & $0.03 \mathrm{~b}$ & $0.03 \mathrm{~b}$ & $0.03 \mathrm{~b}$ & $0.05 \mathrm{a}$ & $0.04 \mathrm{~b}$ & $0.05 \mathrm{a}$ & $0.05 \mathrm{a}$ \\
\hline 'Krakowianka' & $0.04 \mathrm{ab}$ & $0.04 \mathrm{ab}$ & $0.04 \mathrm{ab}$ & $0.03 \mathrm{c}$ & $0.04 \mathrm{ab}$ & $0.04 \mathrm{ab}$ & $0.05 \mathrm{a}$ \\
\hline 'Półdługa' & $0.05 \mathrm{~b}$ & $0.03 \mathrm{c}$ & $0.05 \mathrm{~b}$ & $0.04 \mathrm{~b}$ & $0.04 \mathrm{~b}$ & $0.05 \mathrm{~b}$ & $0.16 \mathrm{a}$ \\
\hline
\end{tabular}

Mean values $(\mathrm{n}=3)$ marked different letter differ statistically (in row, for each cultivar separately) according to Tukey test at $\mathrm{p}<0.05$

The fresh mass of the 'Krakowianka' seedlings watered with extracts from nipplewort organs did not differ significantly from the control. Only a significant reduction of the FM value was observed for the seedlings treated with $5 \%$ shoot extracts. The fresh mass of 'Półdługa' radish was significantly lower for seedlings watered with $5 \%$ extracts from L. communis subsp. communis, relative to the control and all other extracts. 
For the 'Rowa' cultivar, the highest values of relative water content (RWC) were observed for seedlings watered with $1 \%$ nipplewort shoot extract, compared to the control. In other cases, no statistically significant differences in the RWC values were found. The nipplewort extracts had no significant effect on the turgor of 'Krakowianka' cultivar radish seedling cells. The 'Półdługa' cultivar showed a significant reduction in cell turgor (RWC) in seedlings watered with $5 \%$ extracts, compared to the control and $1 \%$ extracts (Table 3 ).

Dry mass (DM) of 'Rowa' seedlings was similar between the control and the seedlings watered with 5\% nipplewort root and shoot extracts. For seedlings watered with $1 \%$ shoot and root extracts and $3 \%$ extracts from roots of L. communis subsp. communis a significant decrease in the DM was observed. Compared to the control, the DM of the 'Krakowianka' cultivar was significantly lower only for seedlings watered with $3 \%$ root extracts. In other cases, no differences in the values of this parameter were found. The dry mass of 'Półdługa' seedlings was the highest in the control, in relation to the DM of seedlings watered with $1 \%$ nipplewort extracts and $3 \%$ root extract (Table 3 ).

Total water content (TWC) of the 'Rowa' and 'Krakowianka' cultivars did not differ significantly, in relation to the control. Only for the 'Półdługa', a significant reduction in the TWC in seedlings watered with $5 \%$ nipplewort shoot extracts was observed (Table 3 ).

The dry-to-fresh mass ratio (DM / FM) for 'Rowa' and 'Póldługa' cultivars was the highest in seedlings watered with 5\% nipplewort shoot extracts, compared to the control. For the 'Krakowianka', the values of this parameter were similar. The lowest DM / FM values for radish seedlings watered with $3 \%$ root $L$. communis subsp. communis extracts were observed (Table 3).

\section{Electrolyte leakage}

Electrolyte leakage (EC), from seedlings of three radish cultivars germinated on the aqueous extracts from roots of $L$. communis subsp. communis, was similar to the control values. A statistically significant increase in this parameter was noted only for the 'Rowa' cultivar, watered with $3 \%$ extract, compared to the control and other extracts and radish cultivars (Figure 4). The 3\% aqueous extracts from nipplewort shoots decreased the percentage of electrolyte leakage for the three studied radish cultivars. On the other hand, the $5 \%$ extracts caused a significant increase in destabilisation of cell membranes. For the 'Krakowianka' cultivar, the $1 \%$ and $3 \%$ extracts statistically reduced the percentage of EC, compared to the control. For the 'Półdługa', the $1 \%$ and $5 \%$ extracts increased the degree of electrolyte outflow, in contrast to the control object and the $3 \%$ extracts which lowered the percentage of EC.

\section{Discussion}

In ecological and agroecological studies, different methods are used to assess the interaction between plants. One of them is the potential use of allelopathy as a natural remedy to control weeds and their harmful effects in agroecosystems (Maqbool et al., 2013; Mahajan et al., 2015; Jabran, 2017; Latif et al., 2017; Scavo et al., 2018; Możdżeń et al., 2020). In this study, an allelopathic model available in the literature was used to determine the effect of aqueous extracts from the roots and shoots of Lapsana communis subsp. communis on radish seeds (a model organism, easy to grow and with a short cycle). Based on the conducted experiment, it was found that each of the used nipplewort extracts showed a clear allelopathic effect on the germination capacity of radish seeds. Analysis of germination indexes showed that, the root extracts turned out to be significantly less toxic than shoot extracts (Table 1, Figure 2). The smallest differences were observed for the germination rate (GR), and the remaining indexes - germination percentage (GP), germination index (GI), seed emergence (SE) and seed vigour index (SVI) provided similar information on the impact of aqueous extracts from $L$. communis subsp. communis. The presented results confirm the inhibitory effect of aqueous extracts of nipplewort roots and shoots, proportional to the concentration of the extract. As the concentration of allelopathic compounds increased, the negative effect of the extracts on the germination of radish seeds 
usually increased (Możdżeń et al., 2020). This kind of reaction of seeds to extracts could have resulted from very early activation of allelopathic compounds. At the swelling stage, these compounds could cause anatomical deformations in the seed coat and spare materials, which contributed to delayed germination (Możdżeń and Rzepka, 2016; Mazur, 2019).

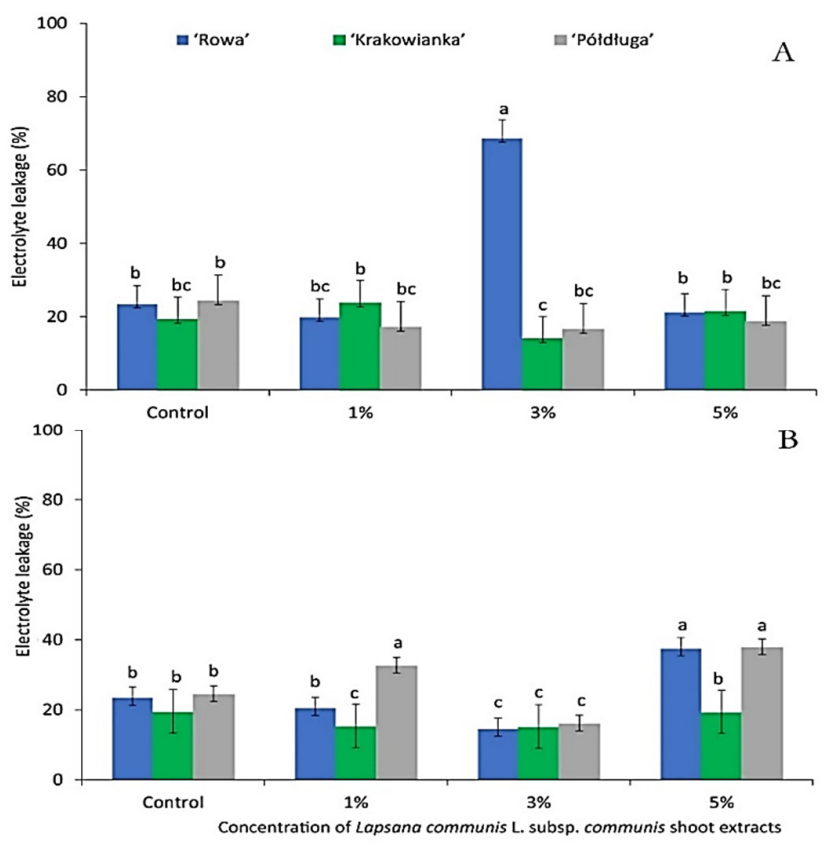

Figure 4. Electrolyte leakage of Raphanus sativus L. var. radicula Pers. 'Rowa', 'Krakowianka' and 'Półdługa' seedlings after 7 days of watered with aqueous extracts from roots (A) and shoots (B) Lapsana communis $\mathrm{L}$. subsp. communis with different percentages (1\%;3\% and 5\%) and under control conditions; mean values $(\mathrm{n}=3, \pm \mathrm{SD})$ marked different letter differ statistically according to Tukey test at $\mathrm{p}<0.05$

Understanding the mutual competition between crops and weeds is possible by comparing the effects of their interaction. This is revealed, for example, in the morphological features of the crop's plants (BielParzymięso, 2020). Changes in the elongation of three radish cultivars expressed as the IP index indicated the effect of extracts from $L$. communis subsp. communis on their growth and development. The values of this index above 0 indicate that the negative allelopathic properties of the analysing plant extracts are intensifying. Negative IP values indicate a positive effect of allelopathic substances contained in the extracts (Islam et al., 2013; Możdżeń et al., 2020). In this experiment, biometric analysis of radish seedlings, regardless of the cultivar, showed a positive effect of root extracts and a negative effect of nipplewort shoot extracts on the growth of underground and aboveground parts of seedlings (Figure 3). Regardless of the type of extract and its concentration, the roots of radish seedlings were shorter than those of the hypocotyls. This may be due to the fact that the roots are the first to come into contact with allelochemical compounds after breaking the seed coat (Mazur, 2019). Apart from inhibiting root elongation, the extracts also caused morphological changes in seedlings (Ashraf et al., 2008). Under the influence of the extracts, the seedlings looked distorted and twisted, compared to the control seedlings.

At the current stage of allelopathic studies, it is assumed that allelochemical compounds co-occurring in the extracts interact not only with the germination capacity of seeds and seedling growth, but also with changes in biomass production (Cheng and Cheng, 2015; Biel-Parzymięso, 2020). In the studies of $L$. communis subsp. communis, the reaction of radish seedlings in terms of the production of fresh and dry mass was specific and depended on the type and concentration of the extract and the cultivar of radish (Table 2). Similar reactions of all radish seedlings, regardless of the cultivar, were found for those watered with 5\% nipplewort shoots extracts. 
In this case, the fresh mass of the seedlings was significantly lower, compared to the control. The dry mass did not differ statistically between the control and 5\% nipplewort root and shoot extracts. On the one hand, this type of reaction may result from the competition for environmental factors between plants growing in the vicinity, and on the other hand, the release of allelochemical compounds into the environment, and consequently their different effects on plants growing in the environment. In agrophytocoenoses, crops plants are forced to compete with weeds for all the environmental components necessary for them to live: light, water, nutrients and space for living. Weeds, by disturbing the availability of any of these factors, cause growth inhibition, yield reduction, resistance to pathogens, lodging and even death of crops plants (Cheng and Cheng, 2015; Scavo et al., 2018). Natural allelochemical compounds can also be involved in the action of growth regulators (Farooq et al., 2013). Therefore, it can be argued that the chemical substances contained in extracts from L. communis subsp. communis, stimulated and inhibited cell division, depending on the type of extract and the concentration of allelopathic compounds.

Allelochemical compounds have a clear effect on the water ratios in the plant (Hussain and Reigosa, 2011; Friedjung et al., 2013). It can be assumed that the phenolic acids, present in the nipplewort extracts, were responsible for the slight differences in the water balance of radish seedlings (Table 2). The presence of these compounds plays an important role in regulating diffusion, as well as maintaining the correct water potential in cells ( $\mathrm{Li}$ et al., 2010; Jacob and Sarada, 2012). However, be aware that this is probably only one of many groups of chemicals substances responsible for this kind of seedling reaction (Cheng and Cheng, 2015). In addition, the activity of allelopathic compounds present in the extracts also depends on their concentration, the $\mathrm{pH}$ of the environment in which they occur and their interaction with other chemicals (Scognamiglio et al., 2013; Nazim Uddin et al., 2020).

Natural allelopathic substances affect not only the water balance of the cell, but also the entire metabolism and all physiological processes (Farooq et al., 2013). By penetrating the cell, allelochemical compounds can modify and even destroy the structures that build cell membranes. Such changes impose limitations on the function of enzyme proteins and induce lipid peroxidation. By disrupting the condition of cell membranes, allelochemical compounds control biochemical and physiological processes in various parts of the cell. In this way, these compounds "decide" on the course of growth and further development of plants (Zandi et al., 2018). In this study, the aqueous extracts from nipplewort roots did not show any significant effect on electrolyte leakage, unlike extracts from shoots (Figure 4). Extracts from the aerial parts of $L$. communissubsp. communis, along with increasing concentrations, disrupted the functioning of radish seedling cell membranes. Probably in the 5\% shoot extracts there was a high concentration of allelochemical compounds, which caused depolarisation and dissolution of the lipid layer of membranes and inhibition of protein biosynthesis. The increased percentage of electrolytes leakage could also result from the insufficient amount of ATP, which is the source of energy necessary to maintain the proper structure of the membranes (Farooq et al., 2013; Możdżen et al., 2020). In the broad spectrum of action of allelochemical compounds, this type of property is mainly attributed to phenolic compounds. However, it cannot be ruled out that other, nonphenolic allelochemical compounds are absorbed on the surface of cell membranes (Cheng and Cheng, 2015). Hence, it is important to conduct further studies of this type in order to identify not only allelochemical compounds, but also to verify the mechanisms modifying the permeability of membranes.

\section{Conclusions}

(1) Germination indexes of radish seeds showed that aqueous extracts of Lapsana communis subsp. communis inhibited germination as the concentration of the extracts increases. The lowest number of germinated seeds was revealed on the Petri dishes with the 5\% extracts.

(2) Elongation growth of radish seedling organs was generally stimulated by root extracts and inhibited by nipplewort leaf extracts. 
(3) The fresh and dry masses varied depending on the type and concentration of the extract. The lowest values were recorded for seedlings germinated on the $5 \%$ of $L$. communis extracts. The water content in seedlings, regardless of the radish cultivar and type of extracts, generally did not differ from the control.

(4) The electrolyte leakages from radish seedlings germinated on the root extracts was similar to the control. A significantly increase of values in this parameter was observed for radish cultivars treated the nipplewort shoot extracts. The most sensitive cultivar on to the effect of the extracts was the 'Póldługa' cultivar, and the most resistant one was the 'Rowa'

The aqueous extracts from nipplewort organs - depending on the concentration and the part they come from - to varying degrees effect the course of physiological processes and morphology of radish seedlings and determine the course of their growth and development. At higher concentrations, especially from the aboveground parts, they have a negative effect on the germination and growth of radish seedlings.

\section{Authors' Contributions}

$\mathrm{KM}, \mathrm{BBK}$ planned and designed the research; KM, PZ performed the experiment; BBK, KM, ASS, PZ analysed the data and prepared figures and tables; BBK, KM, ASS wrote the manuscript. All authors read and approved the final manuscript.

\section{Acknowledgements}

This paper was supported by the Institute of Biology at the Pedagogical University of Krakow, Kraków, Poland (signature: WPBU/2020/05/00172; registration number: BN.610-169/PBU/2020).

\section{Conflict of Interests}

The authors declare that there are no conflicts of interest related to this article.

\section{References}

Abdul-baki BAA, Anderson JD (1973). Relationship between decarboxylation of glutamic acid and vigour in soybean seed. Crop Science 13:222-226. https://doi.org/10.2135/cropsci1973.0011183X001300020023X

Amini S, Azizi M, Joharchi MR, Moradinezhad F (2016). Evaluation of allelopathic activity of 68 medicinal and wild plant species of Iran by Sandwich method. International Journal of Horticultural Science and Technology 3:243-253. https://doi.org/10.22059/ijhst.2016.62923

AOSA (1983). Seed vigor hand testing book. Contribution No. 32 to the handbook on seed testing. Association of Official Seed Analysis. Springfield, IL. pp 122-128.

Ashrafi YZ, Sadeghi S, Mashhadi RH, Hassan AM (2008). Allelopathic effects of sunflower (Helianthus annuus) on germination and growth of wild barley (Hordeum spontaneum). Journal of Agricultural Technology 219-229.

Barralis G, Chadoeuf R, Lonchamp JP (1988). Longevité des semences de mauvais herbes annuelles dans un sol cultivé (Seed longevity of annual weeds in cultivated soil). Weed Research 28(6):407-418. https://doi.org/10.1111/j.1365-3180.1988.tb00821.x

Berkefeld K (1988). Investigations about ecotype formation in Galium aparine L. (Rubiaceae) and Lapsana communis L. (Compositae). Flora (Jena) 181:111-130.

Biel-Parzymięso A (2020). Effect of Morus alba L. leaf extracts on seeds germination and the seedlings growth of Sinapis alba L. and Cucumis sativus L. Annales Universitatis Paedagogicae Cracoviensis Studia Naturae 5:96-109. https://doi.org/10.24917/25438832.5.7 
Bond W, Davies G, Turner R (2007). The biology and non-chemical control of nipplewort (Lapsana communis L.). HDRA, Ryton Organic Gardens, Coventry, CV8, 3LG, UK. gardenorganic.org.uk

Cheng F, Cheng Z (2015). Research progress on the use of plant allelopathy in agriculture and the physiological and ecological mechanisms of allelopathy. Frontiers in Plant Science 6:1020. https://doi.org/10.3389/fpls.2015.01020

Chou CH (1999). Roles of allelopathy in plant biodiversity and sustainable agriculture. Critical Reviews in Plant Sciences 18(5):609-636. https://doi.org/10.1080/07352689991309414

Duke SO, Dayan FE, Rimando AM, Schrader KK, Aliotta G, Oliva A (2002). Chemicals from nature for weed management. Weed Sciences 50:138-151. https://www.jstor.org/stable/4046356

Farooq M, Bajwa AA, Cheema SA, Cheema ZA (2013). Application of allelopathy in crop production. International; Journal of Agriculture and Biology 15:1367-1378.

Fontanel D, Galtier C, Debaouzy JC, Gueiffier A, Viel C (1999). Sesquiterpene lactone glycosides from Lapsana communis L. subsp. communis. Phytochemistry 51:999-1004. https://doi.org/10.1016/S00319422(98)00718-3

Fontanel D, Galtier C, Viel C, Gueiffier A (1998a). Caffeoyl quinic and tartaric acids and flavonoids from Lapsana communis subsp. communis (Asteraceae). Zeitschrift für Naturforschung - Section C Journal of Biosciences 53:10901092.

Fontanel D, Kargol M, Gueiffier A, Viel C (1998b). Triterpene alcohols and fatty acids in lipids and nonsaponifiable matter of Lapsana communis L. subspecies communis (Asteraceae). Journal of the American Oil Chemists Society 75:1457-1459.

Francis A, Darbyshire SJ, Clements DR, DiTommaso A (2011). The biology of Canadian weeds. 146. Lapsana communis L. Canadian Journal of Plant Science 91:553-569. https://doi.org/10.4141/CJPS10169

Friedjung AY, Choudhary SP, Dudai N, Rachmilevitch (2013). Physiological conjunction of allelochemicals and desert plants. Plos One 8(12):e81580. https://doi.org/10.1371/journal.pone.0081580

Fujii Y, Parvez SS, Parvez MM, Ohmae Y, Uda O (2003). Screening of 239 medicinal plant species for allelopathic activity using the sandwich method. Weed Biology Management 3:233-241. https://doi.org/10.1046/j.14446162.2003.00111.x

Hulten E, Fries M (1986). Atlas of North European vascular plants. Part I-III, maps and commentaries. Koeltz Scientific Books, Konigstein, Germany.

Hussain MI, Reigosa MJ (2011). Allelochemical stress inhibits growth, leaf water relations, PSII photochemistry, nonphotochemical fluorescence quenching, and heat energy dissipation in three C3 perennial species. Journal of Experimental Botany 62(13):4533-4545. https://dx.doi.org/10.1093\%2Fjxb\%2Ferr161

Islam AKMA, Anuar N, Yaakob Z (2009). Effect of genotypes and pre-sowing treatments on seed germination behavior of Jatropha. Asian Journal of Plant Sciences 8(6):433-439.

Islam AKMM, Khan MSI, Kato-Noguchi H (2013). Allelopathic activity of Litchi chinensis Sonn. Acta Agriculturae Scandinavica, Section B - Soil and Plant Science 63(8):669-675. https://doi.org/10.1080/ 09064710.2013 .850531

Jabran K (2017). Allelopathy: Introduction and concepts. In: Manipulation of Allelopathic Crops for Weed Control. Springer Briefs in Plant Science. Springer, Cham. https://doi.org/10.1007/978-3-319-53186-1_1

Jabran K, Farooq M, Hussain M, Rehman H, Ali MA (2010) Wild oat (Avena fatua L.) and canary grass (Phalaris minor Ritz.) management through allelopathy. Journal of Plant Protection Research 50:41-44. https://doi.org/10.2478/v10045-010-0007-3

Jacob J, Sarada S (2012). Role of phenolics in allelopathic interactions. Allelopathy Journal 29(2):215-230.

Jarek S, Stachurska-Swakon A (2016). The flora of the Tarnów area (Kotlina Sandomierska Basin). Fragmenta Floristica et Geobotanica Polonica 23(2):243-254.

Kashin AS, Berezutsky MA, Kochanova IS, Dobrynicheva NV, Poljanskaja MV (2007). Peculiarities of seed production in populations of Asteraceae species under impact of anthropogenic factors. Botanical Zhurnal 92:1408-1427.

Khan R, Azim Khan M, Waheedullah, Waqas M, Majid Khan A, Hussain Z, ... Raza MA (2011). Allelopathic potential of Silybum marianum L. against the seed germination of edible legumes. Pakistan Journal Weed of Science Research 17(3):293-302.

Kong CH (2010). Ecological pest management and control by using allelopathic weeds (Ageratum conyzoides, Ambrosia trifida, and Lantana camara) and their allelochemicals in China. Weed Biology and Management 10:73-80. https://doi.org/10.1111/j.1445-6664.2010.00373.x 
Latif S, Chiapusio G, Weston LA (2017). Allelopathy and the role of allelochemicals in plant defence. Advances in Botanical Research 82:19-54. https://doi.org/10.1016/bs.abr.2016.12.001

Li Z-H, Wang Q, Ruan X, Pan C-D, Jiang D-A (2010). Phenolics and plant allelopathy. Molecules 15(12):8933-8952. https://dx.doi.org/10.3390\%2Fmolecules15128933

Liebman, M, Staver CP (2001). Crop diversification for weed management. In: Liebman M, Mohler CL, Staver CP (Eds). Ecological Management of Agricultural Weeds. New York: Cambridge University Press, pp 322-374.

Lipniak K, Kliszcz A (2020). Allelopathic effect of goosefoot on germination and early stage growth of triticale and radish. Annales Universitatis Paedagogicae Cracoviensis Studia Naturae 5:110-128. https://doi.org/10.24917/25438832.5.8

Mahajan G, Sardana V, Chauhan BS (2015). Allelopathy for weed control in agricultural systems. Crop Protection 72:5765. https://doi.org/10.1016/j.cropro.2015.03.004

Maqbool N, Wahid A, Farooq M, Cheema ZA, Siddique KHM (2013). Allelopathy and abiotic stress interaction in crop plants. In: Cheema Z, Farooq M, Wahid A (Eds). Allelopathy. Springer, Berlin, Heidelberg. https://doi.org/10.1007/978-3-642-30595-5_19

Matuszkiewicz W (2020). Przewodnik do oznaczania zbiorowisk roślinnych Polski (Guide to the determination of plant communities in Poland). Wydawnictwo Naukowe PWN, Warszawa.

Mazur A (2019). The role of seed coat in the germination and early stages of growth of bean (Phaseolus vulgaris L.) in the presence of chickweed (Stellaria media (L.) Vill.). Annales Universitatis Paedagogicae Cracoviensis Studia Naturae 4:103-118. https://doi.org/10.24917/25438832.4.6

Milchunas DG, Vandever MW, Ball LO, Hyberg S (2011). Allelopathic cover crop prior to seeding is more important than subsequent grazing/mowing in grassland establishment. Rangeland Ecology and Management 64:291-300. https://doi.org/10.2111/REM-D-10-00117.1

Możdżeń K, Barabasz-Krasny B, Stachurska-Swakoń A, Zandi P, Puła J, Wang Y, Turisová I (2020). Allelopathic interaction between two common meadow plants: Dactylis glomerata L. and Trifolium pratense L. Biologia 75:653-663. https://doi.org/10.2478/s11756-020-00438-6

Możdżeń K, Barabasz-Krasny B, Zandi P, Kliszcz A, Puła J (2020). Effect of aqueous extracts from Solidago canadensis L. leaves on germination and early growth stages of three cultivars of Raphanus sativus L. var. radicula Pers. Plants 9(11):1549. https://doi.org/10.3390/plants9111549

Możdżeń K, Barabasz-Krasny B, Zandi P, Turisová I (2018). Influence of allelopathic activity of Galinsoga parviflora Cav. and Oxalis fontana Bunge on the early growth stages of cultivars Raphanus sativus L. var. radicula Pers. Biologia 73:1187-1195. https://doi.org/10.2478/s11756-018-0144-0

Możdżeń K, Rzepka A, (2016). Rola łupiny nasiennej podczas kiełkowania i wzrostu nasion bobu (Vicia faba L.) w obecności siarczanu ołowiu (The role of the seed coat on germination and growth of broad beans (Vicia faba L.) in lead sulfate conditions). Agronomy Science 71(4):55-65.

Mullan D, Pietragalla J (2012). Leaf relative water content. Physiological breeding II: a field guide to wheat phenotyping CIMMYT, Mexico, pp 25-27.

Nazim Uddin Md, Asaeda T, Shampa SH, Robinson RW (2020). Allelopathy and its coevolutionary implications between native and non-native neighbors of invasive Cynara cardunculus L. Ecology and Evolution 10:74637475. https://doi.org/10.1002/ece3.6472

Puła J, Zandi P, Stachurska-Swakoń A, Barabasz-Krasny B, Możdżeń K, Wang Y (2020). Influence of alcoholic extracts from Helianthus annnus L. roots on the photosynthetic activity of Sinapis alba L. cv. Barka plants. Acta Agriculturae Scandinavica, Section B - Soil and Plant Science 70:8-13. https://doi.org/10.1080/09064710.2019.1661509

Rezendes I, Roncaglio E, Baseggio, Galon L, Brandler D, Tiago C ... Ferreira da Silva A (2020). Allelopathy of weeds on the growth of vegetables. Communication in Plant Sciences 10:7-17. https://doi.org/10.26814/cps2020002

Roberts HA, Neilson JE (1981). Seed survival and periodicity of seedling emergence in twelve weedy species of Compositae. Annals of Applied Biology 97(3):253-334. https://doi.org/10.1111/j.1744-7348.1981.tb05119.x

Scavo A, Restuccia A, Mauromicale G (2018). Allelopathy: principles and basic aspects for agroecosystem control. In: Gaba S, Smith B, Lichtfouse E (Eds). Sustainable Agriculture Reviews. Springer, Cham. https://doi.org/10.1007/978-3-319-90309-5_2

Scognamiglio M, D’Abrosca B, Esposito A, Pacifico S, Monaco P, Fiorentino A (2013). Plant growth inhibitors: allelopathic role or phytotoxic effects? Focus on Mediterranean biomes. Phytochemistry Reviews 12:803-830. https://doi.org/10.1007/s11101-013-9281-9 
Sell PD (1981). Lapsana intermedia Bieb. or Lapsana communis L. subsp. intermedia (Bieb.) Hayek? Watsonia 13:299302.

Sołtys D, Krasuska U, Bogatek R, Gniazdowska A (2013). Allelochemicals as bioherbicides - present and perspectives. In: Price AJ, Kelton JA (Eds). Herbicides - current research and case studies in use. InTech, Rijeka, pp 517-542.

Stachurska-Swakon A (2009). Syntaxonomical revision of the communities with Rumex alpinus L. in the Carpathians. Phytocoenologia 39(2):217-234. https://doi.org/10.1127/0340-269X/2009/0039-0217

Stanciu G, Lupsor S, Arcus M (2007). GC-MS characterization of the volatile oil from Lapsana communis L. Ovidius University Annals of Chemistry 18:72-75.

Towpasz K, Stachurska-Swakoń A (2008). Alder-ash and willow communities and their diversity in the Pogórze Strzyżowskie foothills (Western Carpathians). Acta Societatis Botanicorum Poloniae 77(4):327-338. https://doi.org/10.5586/asbp.2008.043

Urbano B, Gonzalez-Andres F, Ballesteros A (2006). Allelopathic potential of cover crops to control weeds in Barley. Allelopathy Journal 17:53-64.

Weber E, Gut D (2005). A survey of weeds that are increasingly spreading in Europe. Agronomy for Sustainable Development 25:109-121. https://doi.org/10.1051/agro:2004061

Xuan TD, Shinkichi T, Khanh TD, Chung IM (2005) Biological control of weeds and plant pathogens in paddy rice by exploiting plant allelopathy: An Overview. Crop Protection 24:197-206. https://doi.org/10.1016/j.cropro.2004.08.004

Zandi P, Barabasz-Krasny B, Stachurska-Swakoń A, Puła J, Możdżeń K (2018). Allelopathic effects of Stellaria media(L.) Vill. on germination and early stages of growth of Raphanus sativus var. radicula. Annales Universitatis Paedagogicae Cracoviensis Studia Naturae 3:90-99. https://doi.org/10.24917/25438832.3.7
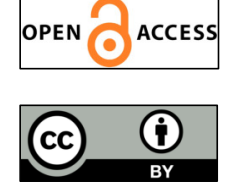

The journal offers free, immediate, and unrestricted access to peer-reviewed research and scholarly work. Users are allowed to read, download, copy, distribute, print, search, or link to the full texts of the articles, or use them for any other lawful purpose, without asking prior permission from the publisher or the author.

License - Articles published in Notulae Botanicae Horti Agrobotanici Cluj-Napoca are Open-Access, distributed under the terms and conditions of the Creative Commons Attribution (CC BY 4.0) License. (c) Articles by the authors; UASVM, Cluj-Napoca, Romania. The journal allows the author(s) to hold the copyright/to retain publishing rights without restriction. 